\title{
The novel, major locus $R p i-p h u 1$ for late blight resistance maps to potato chromosome IX and is not correlated with long vegetation period
}

\author{
J. Śliwka • H. Jakuczun • R. Lebecka • W. Marczewski • \\ C. Gebhardt • E. Zimnoch-Guzowska
}

Received: 13 March 2006 / Accepted: 3 June 2006 / Published online: 12 July 2006

(C) Springer-Verlag 2006

\begin{abstract}
Despite the long history of breeding potatoes resistant to Phytophthora infestans, this oomycete is still economically the most important pathogen of potato worldwide. The correlation of high levels of resistance to late blight with a long vegetation period is one of the bottlenecks for progress in breeding resistant cultivars of various maturity types. Solanum phureja was identified as a source of effective late blight resistance, which was transferred to the cultivated gene pool by interspecific crosses with dihaploids of Solanum tuberosum. A novel major resistance locus, Rpiphul, derived most likely from S. phureja and conferring broad-spectrum resistance to late blight, was mapped to potato chromosome IX, $6.4 \mathrm{cM}$ proximal to the marker GP94. Rpi-phul was highly effective in detached leaflet, tuber slice and whole tuber tests during 5 years of quantitative phenotypic assessment. The resistance did not show significant correlation with vegetation period length. Our findings provide a well-characterized new source of resistance for breeding early and resistant-to- $P$. infestans potatoes.
\end{abstract}

Communicated by R.Waugh

Electronic Supplementary Material Supplementary material is available to authorised users in the online version of this article at http://dx.doi.org/10.1007/s00122-006-0336-9.

\footnotetext{
J. Śliwka $(\bowtie) \cdot$ H. Jakuczun · R. Lebecka · W. Marczewski ·

E. Zimnoch-Guzowska

Plant Breeding and Acclimatization Institute

Research Centre Mł, ochów, Platanowa 19,

05-831 Młochów, Poland

e-mail: j.sliwka@ihar.edu.pl

C. Gebhardt

Max Planck Institute for Plant Breeding Research,

Carl-von-Linné Weg 10, 50829 Cologne, Germany
}

\section{Introduction}

Late blight caused by Phytophthora infestans (Mont.) de Bary threatens potato cultivation worldwide. Chemical control of late blight is expensive and, to be effective, must be constant during the vegetation period. If not controlled, late blight epidemics can result in complete yield loss (Świeżyński and Zimnoch-Guzowska 2001). $P$. infestans is a fast-evolving heterothallic oomycete species, which is able to overcome host resistance by forming new races and which also develops insensitivity to commonly used fungicides.

During the first half of the 20th century, 11 race-specific resistance genes ( $R$ genes), named $R 1-R 11$, have been discovered in the wild species Solanum demissum. Soon afterwards, some of them have been introduced into potato cultivars (Niederhauser et al. 1954; Stewart and Bradshaw 2001). The first gene for late blight resistance that was mapped and subsequently cloned in potato is $R 1$ on chromosome $\mathrm{V}$ (Leonards-Schippers et al. 1994; Ballvora et al. 2002). Other $R$ genes originating from $S$. demissum were mapped to different positions. $R 2$ was localized on chromosome IV ( $\mathrm{Li}$ et al. 1998). Genes $R 3, R 6$ and $R 7$ were all mapped to a distal position on chromosome XI (El-Kharbotly et al. 1994, 1996). Fine mapping of $R 3$ revealed that this resistance is in fact conferred by two closely linked genes $R 3 a$ and $R 3 b$ with distinct pathogen specificities (Huang et al. 2004, 2005). Recently, $R 5, R 8, R 9, R 10$ and $R 11$ genes were shown to be allelic versions of $R 3$ (Huang 2005). Furthermore, R10 and R11 from another source have also been mapped to the same location on chromosome XI in an independent study (Bradshaw et al. 2006).

$R$ genes from $S$. demissum have been exploited in resistance breeding. However, virulence factors of 
P. infestans, which turn those genes ineffective, are widely distributed in the contemporary pathogen populations. The British potato cultivars Pentland Dell $(R 1$, $R 2$ and $R 3)$ and Maris Peer $(R 1, R 2)$ as well as the Polish cv. Epoka $(R 3, R 4)$ are well-documented examples of non-durable resistance to $P$. infestans conferred by these $R$ genes (Malcolmson 1969; Rudkiewicz 1985). From the wild species Solanum berthaultii, gene $R_{\text {pi-ber }}$ was introgressed to the cultivated potato gene pool and mapped to chromosome X (Ewing et al. 2000; Rauscher et al. 2006). Other wild species that cannot be crossed directly with Solanum tuberosum are also important sources of new $R$ genes, such as gene Rpil from Solanum pinnatisectum identified and mapped to chromosome VII (Kuhl et al. 2001) or gene Rpi-mocl found in Solanum mochiquense and mapped to chromosome IX (Smilde et al. 2005), close to locus Ph-3 of Lycopersicon pimpinellifolium, which confers resistance to $P$. infestans in tomato (Chunwongse et al. 2002). A number of resistant genes were identified in the wild species Solanum bulbocastanum. The first two alleles were identified on chromosome VIII and independently cloned by two research groups- $R B$ (Naess et al. 2000; Song et al. 2003) and Rpi-blb1 (Van der Vossen et al. 2003). The second gene Rpi-blb2 is localized on chromosome VI and has also been cloned (Van der Vossen et al. 2005), whereas Rpi-blb3 has been mapped to chromosome IV (Park et al. 2005a). The latter forms an $R$ gene cluster on chromosome IV, together with R2, Rpi-abpt from $S$. bulbocastanum and a $R 2$-like gene of unknown origin (Park et al. 2005b). The $R B$ gene has been introduced into the cultivated potato gene pool by somatic hybridization and Rpi-abpt by bridge crosses. Both genes confer resistance to contemporary $P$. infestans isolates and are being used in breeding programs (Song et al. 2003; Park et al. 2005b).

Besides $R$ genes, quantitative, polygenic or field resistance to $P$. infestans has also been described in potato germplasm and was considered more durable than resistance conferred by $R$ genes (Wastie 1991). The majority of potato cultivars with good levels of field resistance to late blight are, however, late maturing, which is an undesirable agronomic character. The negative correlation between vegetation period length and resistance to $P$. infestans in potato was already reported in the 1950s (Świeżyński 1990) and was explained by concomitant introduction of $S$. demissum genetic factors controlling resistance, both $R$ genes and quantitative resistance loci (QRL), and vegetation period length into the cultivated potato gene pool. Quantitative trait locus (QTL) analysis of late blight resistance and vegetation period length in the same mapping populations could not distinguish whether the correlation between these two traits is due to close genetic linkage between functionally unrelated genes and therefore linkage drag, or to pleiotropic effects of the same gene underlying both traits (Bormann et al. 2004; Collins et al. 1999; Oberhagemann et al. 1999; Visker et al. 2003, 2005).

Here, we describe the identification and linkage mapping of a novel, major late blight QRL originating most likely from Solanum phureja Juz. et Buk., which is highly effective in potato leaves, tuber slices and whole tubers, is not correlated to vegetation period length, and might therefore be a very valuable new resistance source for breeding late blight resistant potato cultivars.

\section{Materials and methods}

Plant materials

The diploid mapping population 97-30 $(2 n=2 x=24)$ was developed by crossing the $P$. infestans resistant clone DG 92-227 with the susceptible clone DG 93-352. Both clones were complex hybrids of $S$. tuberosum and other Solanum species. The original source of resistance is most likely S. phureja Juz. et Buk., included in Solanum stenotomum $\times S$. phureja hybrid $375186.3 / 48$ and into in clone 380051/7 obtained from the International Potato Center, Lima, Peru. A detailed pedigree of DG 92-227 with marked inheritance of resistance to $P$. infestans is shown in S1. Theoretically, DG 92-227 consisted of $S$. phureja-12.5\%, S. stenotomum-6.2\%, S. tuberosum-67.0\%, Solanum chacoense-4.0\%, Solanum gourlayi-6.3\% and Solanum yungasense-4.0\%; while DG 93-352 consisted of $S$. tuberosum-80.9\%, $S$. chacoense-12.7\%, S. gourlayi-3.2\% and S. yungasense-3.2\%. There were 153 progeny clones in the population 97-30. Four Polish potato cvs were used as standards of resistance to $P$. infestans: Irys (susceptible in foliage and tubers), Sokół (susceptible in foliage and moderately resistant in tubers), Bzura (resistant in foliage and susceptible in tubers) and Meduza (resistant in leaflets and moderately resistant in tubers). Additionally, we used two diploid hybrid clones developed at the Laboratory of Genetics, Plant Breeding and Acclimatization Institute (IHAR), Młochów: DG 94-15 with resistant foliage and DG 94-668 with resistant tubers.

\section{P. infestans isolate}

In all resistance tests, the isolate MP 324 from the IHAR pathogen collection was used. The isolate collected in Poland in 1997 was A1 mating type, highly 
aggressive, metalaxyl resistant and of complex race (1.2.3.4.5.6.7.8.10.11). Its virulence was confirmed on Black's differentials (obtained from the Scottish Agricultural Science Agency, Edinburgh, UK) each time parallel to detached leaflet tests assessing the mapping population.

\section{Late blight resistance assessment}

The laboratory assessment of late blight resistance in the population 97-30 was performed in 5 consecutive years 1999-2003. The parental clones and standards were tested together with F1 individuals. Detached leaflet test, tuber slice test and whole tuber test were performed according to Zarzycka (2001a, b). Three or five leaflets, slices or tubers per genotype were tested in two replications once or twice each year. A droplet of 50 sporangia/ $\mu \mathrm{l}$ suspension of $P$. infestans isolate MP 324, prepared as described by Zarzycka (2001a), was used as an inoculum. Resistance of leaflets and tuber slices was assessed after 6 days of incubation. Resistance of whole tubers was assessed after 2 weeks of incubation. The resistance was scored on a 1-9 scale, where 9 was most resistant.

\section{Evaluation of vegetation period length}

Length of vegetation period of the population 97-30, the parental clones and the standards was evaluated in 2 years, 2003 and 2004. In 2003, clones were planted on the 28th of April and harvested on the 18th of September, while in 2004 planting was on the 6th of May and harvesting on the 23rd of September. In both years, a plot of six plants of each genotype was evaluated once a week, starting from the beginning of August. These clones that finished vegetation period before the harvest were evaluated for vegetation period length directly in days. Those which were still growing on the day of harvest were assessed on a 1-5 scale, where 5 means a green, flowering plant, and then the scale was converted into days of vegetation period by adding 7 days per grade above one (Ratuszniak and Komorowska-Jędrys 1995). Therefore, all vegetation period length data were expressed in days.

\section{DNA isolation, PCR and electrophoresis}

Genomic DNA was extracted from $1 \mathrm{~g}$ fresh, young leaves with the DNeasy Plant Maxi kit (Qiagen, Hilden, Germany) according to the supplier's protocol. In bulked segregant analysis (Michelmore et al. 1991), the following were tested: 100 random amplified polymorphic DNA (RAPD) primers, sets A-E, received from
Operon Technologies (Alameda, CA, USA), 21 RAPD primers with known map positions in tomato (McNally and Mutschler 1997) and 100 ISSR (intersimple sequence repeat) primers (set \#9, received from the Biotechnology Laboratory, University of British Columbia, Vancouver, Canada). The bulks contained equal amounts of DNA from eight resistant (resistant bulk) or eight susceptible (susceptible bulk) individuals. Only the individuals with mean resistance grades $\geq 8.1$ in all three types of resistance test were considered as 'resistant'. A pseudo-sequence characterized amplified region (pseudo-SCAR) marker was developed according to the procedure of Chagué et al. (1996). PCR conditions for amplifying RAPD and pseudo-SCAR markers were according to Marczewski et al. (1998), while ISSR markers were analyzed as described by Flis et al. (2005). The Qiaquick kit (Qiagen, Hilden, Germany) was used to recover the amplified DNA from an agarose plug containing the marker OPB7+TG/GT. The sequence of OPB7+TG/ GT amplicon was determined using an ABI PRISM Dye Terminator Cycle Sequencing Ready Reaction Kit and ABI377 automated DNA sequencer (PE Biosystems, Foster City, CA, USA) at the ADIS service unit (Automatische DNA Isolierung und Sequenzierung service unit, MPI, Cologne, Germany). On the basis of the DNA sequence, specific primers were designed to amplify the marker B $7_{600}$. PCR analysis of $\mathrm{B} 7_{600}$ and other sequence-specific markers were performed using the conditions described by Rickert et al. (2003) in $20 \mu \mathrm{l}$ reaction mix containing $1.5 \mathrm{ng} / \mu \mathrm{l}$ template DNA, $1 \times$ PCR buffer (20 mM Tris-HCl, pH 8.0, $50 \mathrm{mM} \mathrm{KCl}$ ), $2.6 \mathrm{mM} \mathrm{MgCl}, 0.2 \mathrm{mM}$ of each dNTP, $0.7 \mu \mathrm{M}$ of each primer, $0.03 \mathrm{U} / \mu \mathrm{l} \mathrm{Taq}$ DNA Polymerase and amplified by the thermocycler program $95^{\circ} \mathrm{C}-2 \mathrm{~min}\left[93^{\circ} \mathrm{C}-\right.$ $1 \mathrm{~min}, 1 \mathrm{~min}$ at annealing temperature, $72^{\circ} \mathrm{C}-$ $1 \mathrm{~min}] \times 40,72^{\circ} \mathrm{C}-10 \mathrm{~min}$. Primer sequences, annealing temperatures and ways of revealing polymorphism are shown in S2. To find polymorphism within amplified DNA fragments, the PCR products were digested with the restriction enzymes MseI, AluI, HinfI, RsaI, DdeI, MspI, DraI, CfoI or TaqI, and separated on agarose gels stained with ethidium bromide [cleaved amplified polymorphic sequence (CAPS) markers]. Alternatively, amplicons were analyzed for single strand conformation polymorphism (SSCP) (Plomion et al. 1999; Slabaugh et al. 1997; Bormann et al. 2004). For SSCP analysis, $4 \mu \mathrm{l}$ of restriction digest with $8 \mu \mathrm{l}$ of denaturing solution (97\% deionized formamide, $0.01 \mathrm{M} \mathrm{NaOH}, 0.05 \%$ xylene cyanol, $0.05 \%$ bromophenol blue) were denatured at $94^{\circ} \mathrm{C}$ for $4 \mathrm{~min}$ and put immediately on ice. Samples were then separated on the $0.25 \times$ Mutation Detection Enhancement gels 
(BMA BioWhittaker Molecular Applications, Rockland, ME, USA) in $53.4 \mathrm{mM}$ Tris-borate, 1.2 EDTA buffer, $\mathrm{pH} 8.0$ and $5 \%$ glycerol with addition of $0.06 \%$ $N, N, N^{\prime}, N^{\prime}$-tetramethylethylenediamine and $0.05 \%$ ammonium persulfate. Gels were run at $1.5 \mathrm{~W}$ for approximately $17 \mathrm{~h}$ at room temperature and silver stained (Bormann et al. 2004).

Mapping of the marker $\mathrm{B}_{600}$

The marker B7 was scored as a segregating SSCP band in the diploid reference mapping population F1840 (Gebhardt et al. 2003). Its position relative to the existing restriction fragment length polymorphism marker database was determined, using the software package MAPRF (E. Ritter, NEIKER, Victoria, Spain).

Data analysis

Goodness-of-fit to normality of the length of vegetation period distribution in the population 97-30 was tested by the Kolmogorov-Smirnov test. Pearson's correlation coefficients between the evaluated traits were calculated. The results of resistance assessment of parental clones and standards were ordered by Duncan's test. Analysis of variance (ANOVA) was performed to assess the effects of year and date of testing, genotype by date, year by date and genotype by year interactions on the results of the resistance tests. Marker alleles were scored as present or absent and their goodness-of-fit to the expected 1:1 segregation ratio was checked by chi-square test. Markers linked to the resistance traits were detected by the Mann-Whitney's $U$-test and the strength of linkage was estimated by ANOVA. The calculations and statistical tests were performed using SPSS 10.0 for Windows (SPSS Inc., Chicago, IL, USA) and STATISTICA for Windows (Stat Soft, Inc., Tulsa, OK, USA).

\section{Results}

Late blight resistance and vegetation period length assessments

Parental clones DG 92-227 (resistant) and DG 93-352 (susceptible), 153 progeny and standards were tested for resistance to $P$. infestans in five consecutive years by three laboratory methods: detached leaflet (in total 11 tests), slice ( 9 tests) and whole tuber tests ( 9 tests). DG 92-227 was more resistant than any other tested clone in all types of tests and its resistance was the most stable in five consecutive years of testing (Table 1). The disease
Table 1 Mean resistance to $P$. infestans of the parental clones (bold) and resistance standards in five years of testing by three laboratory methods: detached leaflet test, tuber slice test and whole tuber test. The resistance was evaluated on a 1-9 scale, where 9 is most resistant. Order of genotypes according to the Duncan test

\begin{tabular}{|c|c|c|c|c|c|}
\hline \multirow{2}{*}{$\begin{array}{l}\text { Clone of } \\
\text { cultivar }\end{array}$} & \multirow{2}{*}{$\begin{array}{l}\text { Number } \\
\text { of tests }\end{array}$} & \multicolumn{4}{|c|}{ Resistance to $P$. infestans } \\
\hline & & $\begin{array}{l}\text { Mean } \\
(1999-2003)\end{array}$ & SD & Range & $\begin{array}{l}\text { Order by } \\
\text { Duncan test }{ }^{\mathrm{a}}\end{array}$ \\
\hline \multicolumn{6}{|c|}{ Detached leaflets } \\
\hline Irys & 11 & 2.68 & 0.72 & $1.5-3.3$ & A \\
\hline DG 94-668 & 11 & 3.31 & 1.06 & $1.8-4.5$ & $\mathrm{AB}$ \\
\hline DG 93-352 & 11 & 3.58 & 1.48 & $2.0-5.5$ & AB \\
\hline Bzura & 11 & 3.63 & 0.87 & $2.5-4.9$ & $\mathrm{AB}$ \\
\hline Sokół & 5 & 4.35 & 0.39 & $3.8-4.9$ & B \\
\hline Meduza & 11 & 6.36 & 0.87 & $4.9-7.2$ & $\mathrm{C}$ \\
\hline DG 94-15 & 11 & 7.98 & 0.59 & $7.0-8.6$ & $\mathrm{D}$ \\
\hline DG 92-227 & 11 & 8.94 & 0.06 & $8.9-9.0$ & D \\
\hline \multicolumn{6}{|c|}{ Tuber slices } \\
\hline Irys & 9 & 2.65 & 1.31 & $1.2-3.8$ & A \\
\hline Bzura & 9 & 2.66 & 0.82 & $1.8-3.8$ & A \\
\hline Sokół & 6 & 3.27 & 0.62 & $2.3-3.5$ & $\mathrm{AB}$ \\
\hline DG 93-352 & 9 & 4.28 & 1.23 & $2.7-5.5$ & B \\
\hline Meduza & 9 & 6.06 & 1.54 & $4.8-8.4$ & $\mathrm{C}$ \\
\hline DG 94-668 & 9 & 7.47 & 0.93 & $7.3-8.9$ & $\mathrm{D}$ \\
\hline DG 94-15 & 9 & 7.54 & 1.03 & $6.4-9.0$ & D \\
\hline DG 92-227 & 9 & 8.90 & 0.22 & $8.5-9.0$ & $\mathbf{E}$ \\
\hline \multicolumn{6}{|c|}{ Whole tubers } \\
\hline Irys & 9 & 4.13 & 0.61 & $3.4-4.7$ & A \\
\hline Sokół & 3 & 5.00 & 0.42 & $4.4-5.6$ & $\mathrm{AB}$ \\
\hline Bzura & 9 & 5.00 & 1.13 & $3.9-6.9$ & $\mathrm{AB}$ \\
\hline DG 93-352 & 9 & 5.79 & 1.42 & 4.5-7.4 & BC \\
\hline Meduza & 9 & 6.06 & 0.42 & $5.5-6.7$ & $\mathrm{BC}$ \\
\hline DG 94-15 & 9 & 6.47 & 0.42 & $6.0-6.9$ & $\mathrm{C}$ \\
\hline DG 94-668 & 9 & 6.50 & 1.23 & $5.4-8.6$ & $\mathrm{C}$ \\
\hline DG 92-227 & 9 & 8.62 & 0.31 & 8.3-9.0 & D \\
\hline
\end{tabular}

$S D$ standard deviation

${ }^{a}$ The same letters indicate lack of significant differences

symptoms observed in this clone fitted the narrow range of grades 8.3-9.0 and were non-sporulating, hypersensitive reaction necroses. DG 93-352 was susceptible in leaflet (mean grade 3.58) and moderately resistant in tuber slice (mean grade 4.28) and whole tuber (mean grade 5.79) tests (Table 1). The resistance standards behaved as expected, the most resistant cultivar was Meduza, the least resistant cv. Irys. Cultivars Bzura and Sokół were moderately resistant and differed significantly from each other only in tuber slice tests. DG 9415 was resistant in all types of tests and was always more resistant than any of the cultivars, whereas DG 94-668 was resistant only in tuber slice and whole tuber tests. The results of progeny resistance assessments in detached leaflet and slice tests covered the whole range of scale 1.0-9.0, whereas the range of results in tuber tests was narrowed to 3.4-9.0 (Fig. 1). The histograms of the 5-year mean resistance among the progeny in all 

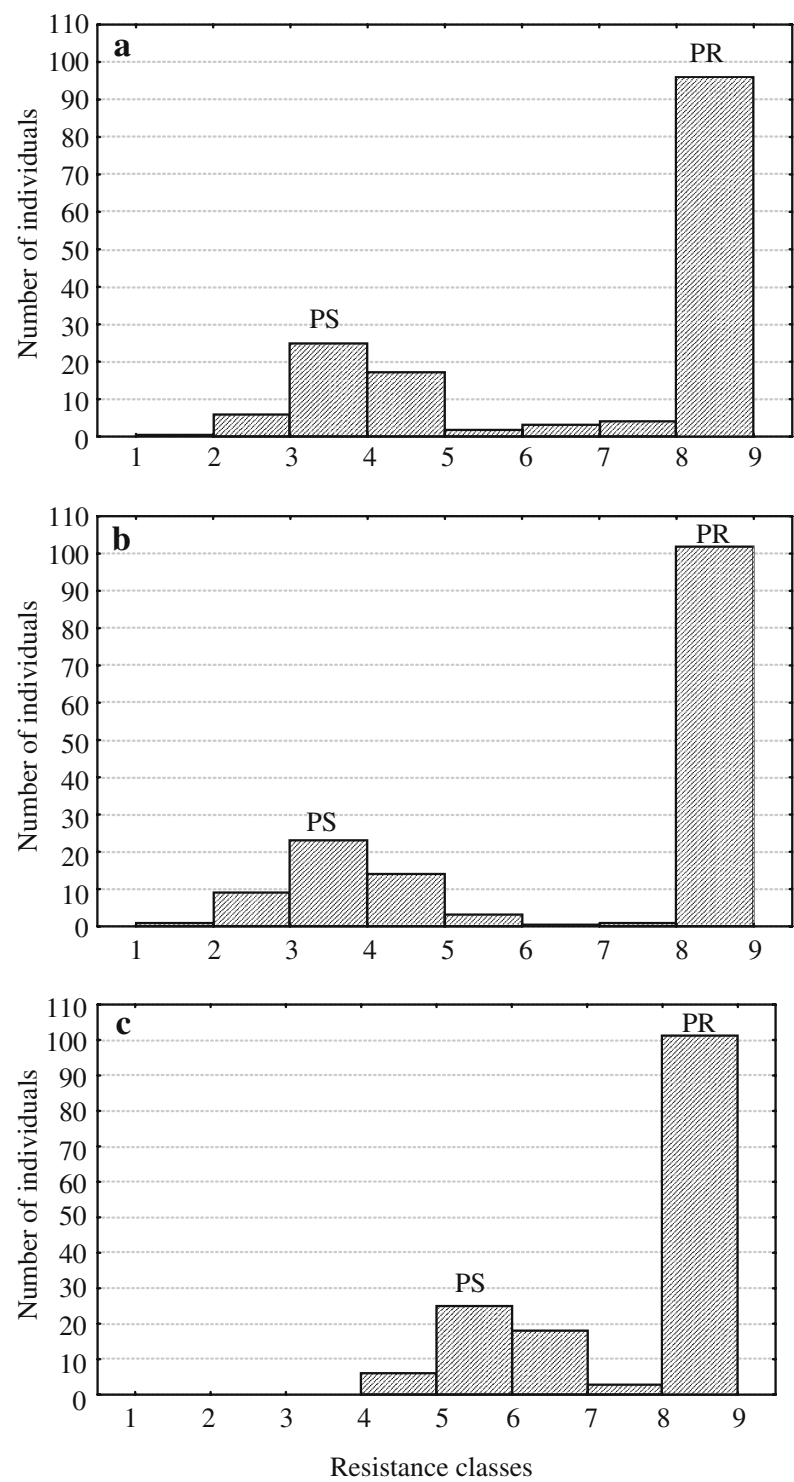

Fig. 1 Frequency distribution of mean (1999-2003) resistance to $P$. infestans of detached leaflets (a), tuber slices (b) and whole tubers (c) in the population 97-30. The resistance was evaluated on a 1-9 scale, where 9 was most resistant. Resistance levels of parents are marked $-P R$ resistant parent DG 92-227, $P S$ susceptible parent DG 93-352

types of tests showed a clear bimodal distribution, indicating the segregation of a major resistance factor in population 97-30. Highly resistant individuals predominated, with resistance of leaflets, tuber slices and whole tubers within the range 8.1-9.0. As in the resistant parent, the scarce symptoms in the progeny could be attributed to a hypersensitive reaction. The ratio of highly resistant (mean $\geq 8.1$ ) to susceptible clones (mean $<8.0$ ) was 103:50, which was significantly different $\left(\chi^{2}=18.36\right.$; $P<0.001)$ from the $1: 1$ ratio expected for a single gene present in the heterozygous state in parent DG 92-227.
According to ANOVA, genotype had the strongest effect on resistance, explaining $76.1,83.4$ and $80.6 \%$ of the variance in leaflet, tuber slice and whole tuber tests, respectively. The effects of year of testing were significant and explained between $2.9 \%$ (tuber slice test) and $4.8 \%$ (leaflet tests) of the variance. The interactions test year $\times$ genotype were also significant and explained $8.7 \%$ of the variance in leaflet tests, $8.5 \%$ in tuber slice tests and $7.5 \%$ in whole tuber tests. The date of testing within the year and interactions date $\times$ year had no significant effect on the results of tuber slice and whole tuber tests. Those factors were, however, significant in leaflet tests, explaining 0.4 and $0.6 \%$ of the variance, respectively.

The mean results of 2-year vegetation period length assessments allowed to classify the resistant clone DG 92-227 as medium late (mean length of vegetation period: 136.3 days) and clone DG $93-352$ as late (147.3 days). The frequency distribution did not significantly deviate from normality according to the Kolmogorov-Smirnov test (Fig. 2). The length of vegetation period varied in population 97-30 from medium early (114.5 days) to late (174.5 days).

\section{Correlations between evaluated traits}

The Pearson's correlation coefficients were calculated for the means of the leaflet, tuber slice and whole tuber resistance and length of vegetation period (Table 2). The resistance of leaflets, slices and tubers was highly correlated, whereas there was no significant correlation between the resistance to $P$. infestans and vegetation period length. No recombinants expressing resistance to $P$. infestans in leaflets and susceptibility in tubers or vice versa were found.

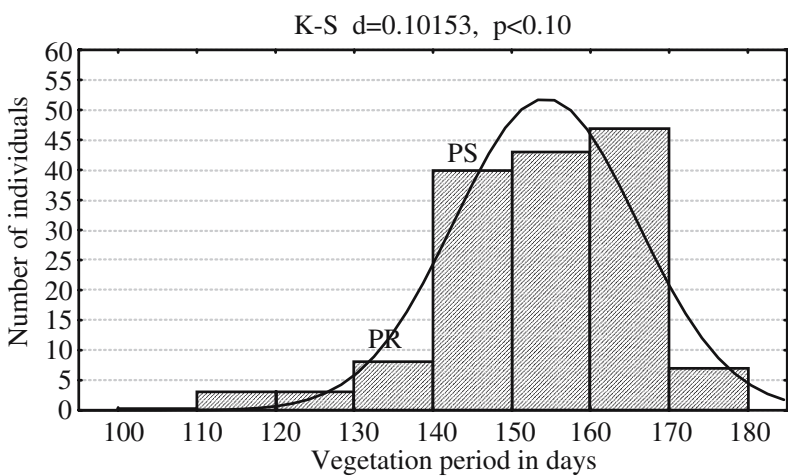

Fig. 2 Frequency distribution of mean (2003-2004) length of vegetation period (in days) in the population 97-30. Goodness-offit to normality is indicated by a curve. $K-S d$ Kolmogorov-Smirnov coefficient, $p$ probability in Kolmogorov-Smirnov test. Length of vegetation period of the parental clones is marked$P R$ resistant parent DG 92-227, $P S$ susceptible parent DG 93-352 
Table 2 Pearson's correlation coefficients between the mean leaflet, tuber slice and whole tuber resistance (1999-2003) and length of vegetation period (2003-2004) of population 97-30

\begin{tabular}{cllll}
\hline & \multicolumn{3}{c}{ Resistance to P. infestans } \\
\cline { 3 - 5 } & Leaflets & $\begin{array}{l}\text { Tuber } \\
\text { slices }\end{array}$ & $\begin{array}{l}\text { Whole } \\
\text { tubers }\end{array}$ \\
\hline Resistance to & Leaflets & - & - & - \\
$P$. infestans & Tuber slices & $0.951 * * *$ & - & - \\
& Whole tubers & $0.942 * * *$ & $0.957 * * *$ & - \\
Length of vegetation period & -0.142 & -0.088 & -0.073 \\
\hline
\end{tabular}

*** Significant at $P<0.000$

Identification of markers linked to late blight resistance

The screening of the population 97-30 with RAPD primers resulted in detection of 744 RAPD fragments, of which 238 (32\%) were polymorphic among the parents. Ninety-five of the polymorphic RAPD fragments were specific for the resistant parent DG 92-227. Using ISSR primers, 497 PCR amplicons were obtained, with 167 (34\%) showing polymorphism among the parents, of which 85 were found only in the resistant parent. PCR amplification of the 180 polymorphic markers in bulked DNA samples revealed one RAPD marker of $800 \mathrm{bp}$, which was amplified by primer OPB7 (5'ggt gac gca g $\left.3^{\prime}\right)$ and was present in resistant parent, the resistant DNA bulk and in all eight individuals constituting the resistant bulk. A fragment of similar size as $\mathrm{OPB}_{800}$ was observed in susceptible samples. The intensity of this fragment on stained gels was, however, lower than that obtained with DNA from resistant plants. To increase marker specificity, the marker OPB7+TG/GT was developed carrying two additional nucleotides at the $3^{\prime}$ end of the RAPD 10-mer. Using the primers OPB7+TG and OPB7+GT resulted in the amplification of the $800 \mathrm{bp}$ marker OPB7+TG/GT found as a clear bright band in resistant clones (Fig. 3a). This marker was then scored in all 153 progeny plants. When treating the major late blight QRL as a single gene, considering all individuals with a resistance score $\geq 8.1$ as resistant and the rest as susceptible, marker OPB7+TG/GT was linked with $12.3 \%$ recombination to the resistance locus. The locus was named Rpi-phu1. Based on the sequence of OPB7+TG/GT, the SSCP marker $\mathrm{B}_{600}$ was developed. Polymorphism of marker $\mathrm{B}_{600}$ in the population 97-30 was revealed after restriction with $M s e I$ and SSCP analysis. An MseI restriction fragment of $\mathrm{B}_{600}$ was observed in the resistant parent DG 92-227, which co-segregated with OPB7+TG/GT in population 97-30 (not shown).

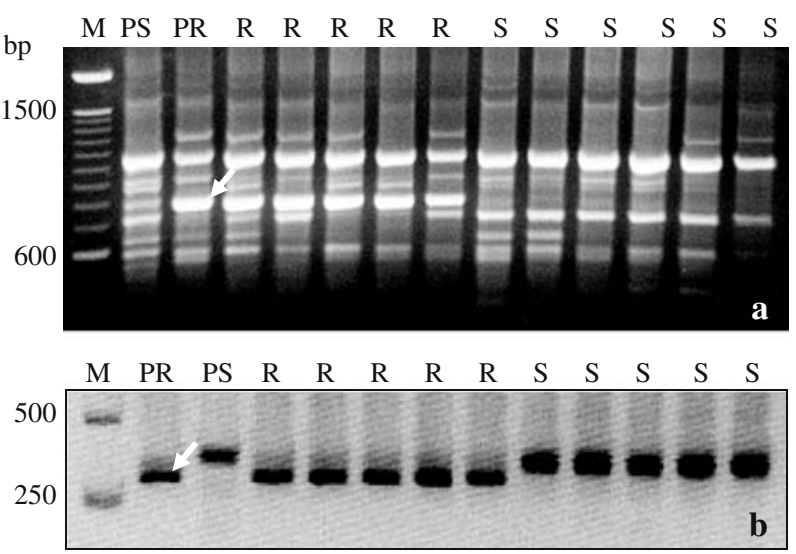

Fig. 3 PCR amplification of markers pseudo-SCAR OPB07+TG/GT (a) and GP94 (b) on parental clones and samples of the 97-30 progeny. $M$ DNA ladder (a-100 bp DNA ladder, b-250 bp DNA ladder), $P R$ resistant parent DG 92-227, $P S$ susceptible parent DG 93-352, $R$ resistant progeny F1, $S$ susceptible progeny $\mathrm{F} 1$. The white arrow indicates an 800-bp marker band of OPB07+TG/GT (a) or 350-bp marker band of GP94 (b)

Genetic mapping of the locus Rpi-phu1

Segregation analysis of the marker $\mathrm{B}_{600}$ in a reference mapping population F1840 (Gebhardt et al. 2003) indicated the map position of the locus Rpi-phul on potato chromosome IX in the vicinity of marker GP94 (not shown). GP94 showed a size polymorphism in the parents of the population 97-30 (Fig. 3b). The 350-bp fragment present in the resistant parent co-segregated with the resistance in progeny, apart from $6.4 \%$ of recombinants between GP94 and Rpi-phu1 (Fig. 4). The chromosome IX specific markers GP39, GP129, CP135 and S1D11 were scored by PCR in population 97-30 to localize the resistance locus on chromosome IX more precisely (Fig. 4). The marker alleles of GP39, B7, GP94, GP129 and CP135 inherited from the resistant parent segregated, similar to the resistance, in 2:1 ratio according to chi-square test: GP39 $\left(\chi^{2}=0.09 ; P>0.50\right)$, OPB7 $\left(\chi^{2}=0.09 ; P>0.50\right)$, GP94 $\left(\chi^{2}=1.39 ; P>0.20\right)$, $\operatorname{GP129}\left(\chi^{2}=2.54 ; P>0.10\right)$ and $\operatorname{CP135}\left(\chi^{2}=3.13 ; P>0.05\right)$.

\section{QTL analysis}

Besides the markers on potato chromosome IX, the population 97-30 was analyzed for 194 sequence-specific markers located on the other 11 potato chromosomes, chosen preferentially from map regions previously described as having QTL for length of vegetation period and/or resistance to $P$. infestans (Gebhardt and Valkonen 2001; Gebhardt 2004; Visker et al. 2005). After amplification and CAPS and SSCP analyses, 20 markers were polymorphic in population 97-30. 
Fig. 4 Linkage map of chromosome IX of the resistant parent DG 92-227 showing the position of the Rpi-phu1 locus. Genetic distances are shown in $\mathrm{cM} .{ }^{l}$ Markers were amplified according to Rickert et al. $2003,{ }^{2}$ markers were amplified according to Marczewski et al. 2006

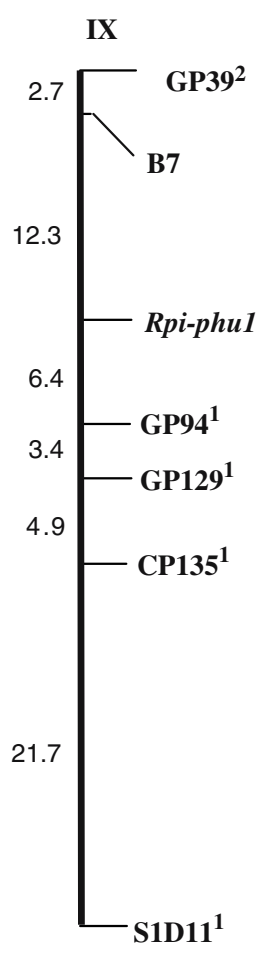

All segregating markers, including the markers on chromosome IX, were tested by Mann-Whitney's $U$-test for linkage to QTL for length of vegetation period and resistance to $P$. infestans. For those markers which were significantly linked with the traits, the amount of variance explained by the marker was estimated by ANOVA. All chromosome IX markers were highly significantly linked to late blight resistance (Table 3 ). The marker GP94 explained the largest amount of the variance $(65-68 \%)$, thereby confirming the position of the major locus Rpi-phul. Four additional, minor QTL affecting resistance to $P$. infestans and/or length of vegetation period were found on chromosomes IV, V, VIII and X. The QTL on chromosome V showed the strongest effect on vegetation period length, explaining $8.9 \%$ of variance in 2-year means of this trait observed in population 97-30. A QTL for length of the vegetation period was detected also on chromosome IX linked to the two most distal markers GP39 and OPB07+GT/TG (Fig. 4, Table 3). However, marker GP94, which was most closely linked to Rpi-phu1, did not show significant linkage with length of the vegetation period.

\section{Discussion}

The gene Rpi-phul, mapped in this study, is particularly interesting because it provides high level of resistance to $P$. infestans in tubers as well as in foliage. One of the most important aspects of breeding late blight resistant potatoes is tuber resistance, since the blighted tubers can rot in storage or become a source of primary inoculum after planting as seeds (Świeżyński and Zimnoch-Guzowska 2001). However, little is known about $R$ gene expression and effectiveness in tubers, because those genes were usually identified on the basis of testing leaflet or foliage resistance. Expression of tuber resistance depends on the tissue inoculated (Świeżyński and Zimnoch-Guzowska 2001). The tuber skin and the cambial layer just underneath the tuber skin can be important barriers for infection (Toxopeus 1958, 1961), but the periderm, cortex and medulla can also be involved in tuber resistance (Flier et al. 2001).

Table $3 P$ values (Mann-Whitney's $U$-test) and $R^{2}$ values for significant linkages of markers originating from the resistant parent DG 92-227 with the all year means of detached leaflet tests, tuber slice tests, whole tuber tests and length of vegetation period

\begin{tabular}{|c|c|c|c|c|c|c|c|c|c|}
\hline \multirow[t]{2}{*}{$\mathrm{Ch}$} & \multirow[t]{2}{*}{ Marker } & \multicolumn{4}{|l|}{$P$} & \multicolumn{4}{|l|}{$R^{2}$} \\
\hline & & $\begin{array}{l}\text { Leaflets } \\
\text { 1999-2003 }\end{array}$ & $\begin{array}{l}\text { Slices } \\
1999-2003\end{array}$ & $\begin{array}{l}\text { Tubers } \\
1999-2003\end{array}$ & $\begin{array}{l}\text { Veg. } \\
\text { 2003-2004 }\end{array}$ & $\begin{array}{l}\text { Leaflets } \\
1999-2003\end{array}$ & $\begin{array}{l}\text { Slices } \\
1999-2003\end{array}$ & $\begin{array}{l}\text { Tubers } \\
1999-2003\end{array}$ & $\begin{array}{l}\text { Veg. } \\
\text { 2003-2004 }\end{array}$ \\
\hline IV & BA106 c14 t7 & ns & ns & ns & 0.041 & ns & ns & ns & 3.5 \\
\hline V & $\begin{array}{l}\text { BA100 e } 13 \text { A/B } \\
\text { BA151 m } 8 \text { C/D }\end{array}$ & $\begin{array}{l}\mathrm{ns} \\
\mathrm{ns}\end{array}$ & $\begin{array}{l}\text { ns } \\
0.034\end{array}$ & $\begin{array}{l}0.022 \\
0.002\end{array}$ & $\begin{array}{l}0.001 \\
0.010\end{array}$ & $\begin{array}{l}\mathrm{ns} \\
\mathrm{ns}\end{array}$ & $\begin{array}{l}\mathrm{ns} \\
3.7\end{array}$ & $\begin{array}{l}3.6 \\
5.4\end{array}$ & $\begin{array}{l}8.9 \\
3.7\end{array}$ \\
\hline VIII & $\begin{array}{l}573 \\
\text { BA73 e } 8 \text { t3 }\end{array}$ & $\begin{array}{l}0.021 \\
\text { ns }\end{array}$ & $\begin{array}{l}0.002 \\
\mathrm{~ns}\end{array}$ & $\begin{array}{l}0.037 \\
\mathrm{~ns}\end{array}$ & $\begin{array}{l}\text { ns } \\
0.011\end{array}$ & $\begin{array}{l}2.3 \\
\mathrm{~ns}\end{array}$ & $\begin{array}{l}2.0 \\
\mathrm{~ns}\end{array}$ & $\begin{array}{l}1.6 \\
\mathrm{~ns}\end{array}$ & $\begin{array}{l}\mathrm{ns} \\
4.5\end{array}$ \\
\hline IX & $\begin{array}{l}\text { GP39 } \\
\text { OPB } 07\end{array}$ & $\begin{array}{l}0.000 \\
0.000\end{array}$ & $\begin{array}{l}0.000 \\
0.000\end{array}$ & $\begin{array}{l}0.000 \\
0.000\end{array}$ & $\begin{array}{l}0.004 \\
0.005\end{array}$ & $\begin{array}{l}42.7 \\
50.2\end{array}$ & $\begin{array}{l}41.6 \\
47.9\end{array}$ & $\begin{array}{l}51.0 \\
46.6\end{array}$ & $\begin{array}{l}5.4 \\
5.4\end{array}$ \\
\hline & GP94 & 0.000 & 0.000 & 0.000 & ns & 66.7 & 68.3 & 65.4 & ns \\
\hline & GP129 & 0.000 & 0.000 & 0.000 & ns & 55.1 & 57.2 & 54.4 & $\mathrm{~ns}$ \\
\hline & CP135 & 0.000 & 0.000 & 0.000 & $\mathrm{~ns}$ & 42.1 & 43.3 & 41.2 & ns \\
\hline & S1D11 & 0.000 & 0.000 & 0.000 & ns & 8.4 & 10.4 & 9.6 & ns \\
\hline $\mathrm{X}$ & CP105 & 0.044 & 0.021 & 0.019 & ns & 4.6 & 5.0 & 3.5 & ns \\
\hline
\end{tabular}

Ch chromosome, leaflets, slices, tubers mean (1999-2003) resistance to P. infestans in detached leaflet, slice and tuber tests, veg. mean (2003-2004) length of vegetation period, $n s$ not significant 
Recently, Park et al. (2005c) showed that the genes Rpi-abpt and $R 3 a$ are foliage-specific, while $R 1$ or $R 1$ like is effective both in tubers and foliage, confirming previous findings of Roer and Toxopeus (1961), who also investigated the effects of $R 1$ and $R 3$ on tuber resistance. The $R 2$ gene has also been shown to be foliage-specific (Roer and Toxopeus 1961). In case of the $R B$ gene, although its expression was shown both in foliage and tubers, it may not be responsible for the tuber blight resistance (Millet and Bradeen 2005).

The disease symptoms caused by $P$. infestans and observed in the resistant parent DG 92-227 were nonsporulating, hypersensitive reaction necroses, which indicated the action of a putative $R$ gene in this clone. The large group of highly resistant individuals in the population 97-30 expressed only hypersensitivity and was clearly distinct from the group of susceptible individuals. The level of resistance conferred by Rpi-phul was higher in leaflets, tuber slices and in whole tubers when compared to the levels of any of the resistance standards tested. The resistance of the evaluated plant parts was highly correlated, indicating the action of the same genetic factor on all three resistance traits. In tubers, the blight resistance was expressed irrespective of the tissue inoculated. Highly correlated results were obtained from tuber slice tests, where the medulla was inoculated and from whole tuber tests, where mostly the periderm and the cambial layer were inoculated, although the range of reactions in whole tuber tests was narrowed in comparison to tuber slice tests. From the technical point of view, the tuber slice was more accurate and less time-consuming, while the whole tuber test better reflects the situation occurring in nature. The influence of the environment on the resistance expression was weak, since the most important source of variation in resistance over the five years of testing was genotype.

Genetic mapping of the resistance factor, treating it either as an $R$ gene or as QRL, identified a novel locus Rpi-phul in a central region on potato chromosome IX, $6.4 \mathrm{cM}$ proximal to the anchor marker GP94. Resistance and the linked markers segregated in 2:1 mode. This segregation distortion could be due to the hybrid character of the investigated material. In the pedigrees of both parental clones, there were a number of identical ancestors, sometimes used repeatedly. That could have been a way of accumulating lethal loci, frequently found in potato, which is a species suffering from inbreeding depression (Ortiz and Peloquin 1994). Only the most distal marker S1D11 segregated in a normal $1: 1$ ratio $\left(\chi^{2}=0.32 ; P>0.50\right)$. Rpi-phu1 may be a member of a new 'hotspot' for resistance in Solanaceous genomes. The gene Gm conferring resistance to Potato virus $M$ has been recently identified in a similar region on potato chromosome IX (Marczewski et al. 2006), as well as a QTL for resistance to Erwinia carotovora ssp. atroseptica (Zimnoch-Guzowska et al. 2000).

Comparing the position of Rpi-phu1 with the Solanaceae function map for pathogen resistance (https:// gabi.rzpd.de/projects/Pomamo/), Rpi-phul is located proximal to resistance gene clusters in the more distal regions of chromosome IX. The resistance gene cluster 'to the South' contains the late blight resistance gene Rpi-moclof S. mochiquense (Smilde et al. 2005), Ph-3, a major QRL for late blight resistance in tomato (Chungwongse et al. 2002), $S w-5$, a tomato gene for tospoviruses resistance (Brommonschenkel and Tanksley 1997), $N x$ encoding hypersensitive resistance to Potato virus $X$ of $S$. phureja (Tommiska et al. 1998) and Gpa6, a QTL for potato resistance to Globodera pallida (Rouppe van der Voort et al. 2000). Resistance loci 'to the North' of Rpi-phul are Tm-2a from Solanum peruvianum conferring resistance to Tomato mosaic virus (Tanksley et al. 1992), Frl for tomato resistance to Fusarium oxysporum f. sp. radicis-lycopersici (Zhang et al. 2003) and Vel for resistance to Verticillium dahliae in tomato and potato (Kawchuk et al. 2001; Simko et al. 2004).

There was no significant correlation between the resistance conferred by Rpi-phul and vegetation period length. This is an important finding, because late blight resistance of commercial value should be highly effective, durable and not linked with unwanted traits such as long vegetation period or late maturity. The few QTLs for vegetation period length tagged in population 97-30 are in accordance with published data. The most important QTL for vegetation period length has been repeatedly identified on potato chromosome $\mathrm{V}$ in the vicinity of the $R 1$ locus and overlapped with QTL for late blight resistance (Collins et al. 1999; Oberhagemann et al. 1999; Bormann et al. 2004; Bradshaw et al. 2004; Visker et al. 2003, 2005). QTLs for vegetation period length on chromosomes IV, VIII and IX have also been detected in the QTLs tagging experiment of Bormann et al. (2004). Most of the late blight resistance present within potato cultivars originates from $S$. demissum and their lateness used to be attributed to the linkage drag (Umaerus and Umaerus 1994). Świeżyński (1990) postulated that the negative correlation between vegetation period length and late blight resistance is rather physiologically determined and therefore difficult to break. That is in accordance with a new description of types of resistance to late blight by Allefs et al. (2005) who name the two types of resistance ' $R$-gene based' and 'maturity related', with the underlying hypothesis that 
any resistance level higher than expected on the basis of maturity class must be due to $R$ genes. Still, there is a lack of the direct, experimental evidence on the nature of the relation between late blight resistance and vegetation period length, especially in the context of different resistance sources.

Acknowledgments The authors thank Agim Ballvora and Andreas Rickert for providing PCR primers.

\section{References}

Allefs JJHM, Muskens MWM, van der Vossen EAG (2005) Breeding for foliage blight resistance in the genomics era. In: Haverkort AJ, Striuk PC (eds) Potato in progress. Science meets practice. Academic, Wageningen, pp. 255-267

Ballvora A, Ercolano MR, Weiss J, Meksem K, Bormann CA, Oberhagemann P, Salamini F, Gebhardt C (2002) The RI gene for potato resistance to late blight (Phytophthora infestans) belongs to the leucine zipper/NBS/LRR class of plant resistance genes. Plant J 30:361-371

Bormann CA, Rickert AM, Castillo Ruiz RA, Paal J, Lübeck J, Strahwald J, Buhr K, Gebhardt C (2004) Tagging quantitative trait loci for maturity-corrected late blight resistance in tetraploid potato with PCR-based candidate gene markers. Mol Plant Microbe Interact 17:1126-1138

Bradshaw JE, Pande B, Bryan GJ, Hackett CA, McLean K, Stewart HE, Waugh R (2004) Interval mapping of quantitative trait loci for resistance to late blight [Phytophthora infestans (Mont.) de Bary], height and maturity in a tetraploid population of potato (Solanum tuberosum subsp. tuberosum). Genetics 168:983-995

Bradshaw JE, Bryan GJ, Lees AK, McLean K, Solomon-Blackburn RM (2006) Mapping the $R 10$ and $R 11$ genes for resistance to late blight (Phytophthora infestans) present in the potato (Solanum tuberosum) R-gene differentials of Black. Theor Appl Genet 112:744-751

Brommonschenkel SH, Tanksley SD (1997) Map-based cloning of the tomato genomic region that spans the Sw-5 tospovirus resistance gene in tomato. Mol Gen Genet 256:121-126

Chagué V, Mercier JC, Guénard M, de Courcel A, Vedel F (1996) Identification and mapping on chromosome 9 of RAPD markers linked to $S w-5$ in tomato by bulked segregant analysis. Theor Appl Genet 92:1045-1051

Chunwongse J, Chunwongse C, Black L, Hanson P (2002) Molecular mapping of the $\mathrm{Ph}-3$ gene for late blight resistance in tomato. J Hortic Sci Biotechnol 77:281-286

Collins A, Milbourne D, Ramsay L, Meyer R, Chatot-Balandras C, Oberhagemann P, De Jong W, Gebhardt C, Bonnel E, Waugh R (1999) QTL for field resistance to late blight in potato are strongly correlated with maturity and vigour. Mol Breed 5:387-398

El-Kharbotly A, Leonards-Schippers C, Huigen DJ, Jacobsen E, Pereira A, Stiekema WJ, Salamini F, Gebhardt C (1994) Segregation analysis and RLFP mapping of the $R 1$ and $R 3$ alleles conferring race-specific resistance to Phytophthora infestans in progeny of dihaploid potato parents. Mol Gen Genet 242:749-754

El-Kharbotly A, Palomino-Sánchez C, Salamini F, Jacobsen E, Gebhardt C (1996) $R 6$ and $R 7$ alleles of potato conferring race-specific resistance to Phytophthora infestans (Mont.) de Bary identified genetic loci clustering with the $R 3$ locus on chromosome XI. Theor Appl Genet 92:880-884
Ewing EE, Simko I, Smart CD, Bonierbale MW, Mizubuti ESG, May GD, Fry WE (2000) Genetic mapping from field tests of qualitative and quantitative resistance to Phytophthora infestans in a population derived from Solanum tuberosum and Solanum berthaultii. Mol Breed 6:25-36

Flier WG, Turkensteen LJ, van den Bosch GMB, Verijken PFG, Mulder A (2001) Differential interaction of potato cultivars with different levels of blight resistance. Plant Pathol 50:292301

Flis B, Hennig J, Strzelczyk-Żyta D, Gebhardt C, Marczewski W (2005) The Ry-fsto gene from Solanum stoloniferum for extreme resistant to Potato virus $Y$ maps to potato chromosome XII and is diagnosed by PCR marker GP122718 in PVY resistant potato cultivars. Mol Breed 15:95-101

Gebhardt C (2004) Potato genetics: maps and more. In: Lörtz H, Wenzel G (eds) Molecular marker systems in plant breeding and crop improvement. Biotechnology in agriculture and forestry. Springer, Berlin Heidelberg New York, pp. 55:215-227

Gebhardt C, Valkonen JPT (2001) Organization of genes controlling disease resistance in the potato genome. Annu Rev Phytopathol 39:79-102

Gebhardt C, Walkemeier B, Henselewski H, Barakat A, Delseny M, Stüber K (2003) Comparative mapping between potatoes (Solanum tuberosum) and Arabidopsis thaliana reveals structurally conserved domains and ancient duplications in the potato genome. Plant J 34:529-541

Huang S (2005) Discovery and characterization of the major late blight resistance complex in potato. Thesis, Wageningen University

Huang S, Vleeshouwers VGAA, Werij JS, Hutten RCB, van Eck HJ, Visser RGF, Jacobsen E (2004) The $R 3$ resistance to Phytophthora infestans in potato is conferred by two closely linked $R$ genes with distinct specificities. Mol Plant Microbe Interact 17:428-435

Huang S, van der Vossen EAG, Kuang H, Vleeshouwers VGAA, Zhang N, Borm JA, van Eck HJ, Baker B, Jacobsen E, Visser RGF (2005) Comparative genomics enabled the isolation of the $R 3 a$ late blight resistance gene in potato. Plant J 42:251-261

Kawchuk LM, Hachey J, Lynch DR, Kulcsar F, van Rooijen G, Waterer DR, Robertson A, Kokko E, Byers R, Howerd HR, Fischer R, Prüfer D (2001) Tomato Ve disease-resistance genes encode cell surface-like receptors. Proc Natl Acad Sci USA 98:6511-6515

Kuhl JC, Hanneman RE Jr, Havey MJ (2001) Characterization and mapping of Rpil, a late-blight resistance locus from diploid (1EBN) Mexican Solanum pinnatisectum. Mol Genet Genomics 265:977-985

Leonards-Schippers C, Gieffers W, Salamini F, Gebhardt C (1992) The R1 gene conferring race-specific resistance to Phytophthora infestans in potato is located on potato chromosome V. Mol Gen Genet 233:278-283

Li X, van Eck HJ, Rouppe van der Voort JNAM, Huigen DJ, Stam P, Jacobsen E (1998) Autotetraploids and genetic mapping using common AFLP markers: the $R 2$ allele conferring resistance to Phytophthora infestans mapped on potato chromosome 4. Theor Appl Genet 96:1121-1128

Malcolmson JF (1969) Races of Phytophthora infestans occurring in Great Britain. Trans Br Mycol Soc 53:417-423

Marczewski W, Ostrowska K, Zimnoch-Guzowska E (1998) Identification of RAPD markers linked to the Ns locus in potato. Plant Breed 117:88-90

Marczewski W, Strzelczyk-Żyta D, Hennig J, Witek K, Gebhardt C (2006) Potato chromosomes IX and XI carry genes for resistance to potato virus M. Theor Appl Genet 112:12321238 
McNally KL, Mutschler MA (1997) Use of introgression lines and zonal mapping to identify RAPD markers linked to QTL. Mol Breed 3:203-212

Michelmore RW, Paran I, Kesseli RV (1991) Identification of markers linked to disease resistance genes by bulked segregant analysis: a rapid method to detect markers in specific genetic regions using segregating populations. Proc Natl Acad Sci USA 88:9828-9832

Millett BP, Bradeen JM (2005) Does the foliar resistance $R$ gene $R B$ function for tuber blight control? In: Abstracts of plant and animal genomes XIII conference, San Diego, 15-19 January $2005,486 \mathrm{pp}$

Naess SK, Bradeen JM, Wielgus SM, Haberlach GT, McGrath JM, Helgeson JP (2000) Resistance to late blight in Solanum bulbocastanum is mapped to chromosome 8. Theor Appl Genet 101:697-704

Niederhauser JS, Cervantes J, Servin L (1954) Late blight in Mexico and its implications. Phytopathology 44:406-408

Oberhagemann P, Chatot-Balandras C, Schäfer-Pregl R, Wegener D, Palomino C, Salamini F, Bonnel E, Gebhardt C (1999) A genetic analysis of quantitative resistance to late blight in potato: towards marker-assisted selection. Mol Breed 5:399_ 415

Ortiz R, Peloquin SJ (1994) Use of 24-chromosome potatoes (diploids and dihaploids) for genetical analysis. In: Bradshaw JE, Mackay GR (eds) Potato genetics. CAB International, Wallinford, pp. 133-154

Park T-H, Gros J, Sikkema A, Vleeshouwers VGAA, Muskens M, Allefs S, Jacobsen E, Visser RGF, van der Vossen EAG (2005a) The late blight resistance locus Rpi-blb3 from Solanum bulbocastanum belongs to a major late blight $R$ gene cluster on chromosome 4 of potato. Mol Plant Microbe Interact 18:722-729

Park T-H, Vleeshouwers VGAA, Hutten RCB, van Eck HJ, van der Vossen EAG, Jacobsen E, Visser RGF (2005b) Highresolution mapping and analysis of the resistance locus Rpiabpt against Phytophthora infestans in potato. Mol Breed 16:33-43

Park T-H, Vleeshouwers VGAA, Kim J-B, Hutten RCB, Visser RGF (2005c) Dissection of foliage and tuber blight resistance in mapping populations of potato. Euphytica 143:75-83

Plomion C, Hurme P, Frigerio J-M, Ridolfi M, Pot D, Pionneau C, Avila C, Gallardo F, David H, Neutelings G, Campbell M, Canovas FM, Savolainen O, Bodénès C, Kremer A (1999) Developing SSCP markers in two Pinus species. Mol Breed 5:21-31

Ratuszniak E, Komorowska-Jędrys J (1995) Metodyka prowadzenia badań i obserwacji w doświadczeniach wstępnych z rodami hodowlanymi (odmianami) ziemniaka (instrukcja). Instytut Ziemniaka, Bonin

Rauscher GM, Smart CD, Simko I, Bonierbale M, Mayton H, Greenland A, Fry WE (2006) Characterization and mapping of $R_{\text {pi-ber }}$, a novel potato late blight resistance gene from Solanum berthaultii. Theor Appl Genet 112:674-687

Rickert AM, Kim JH, Meyer S, Nagel A, Ballvora A, Oefner PJ, Gebhardt C (2003) First-generation SNP/InDel markers tagging loci for pathogen resistance in the potato genome. Plant Biotechnol J 1:399-410

Roer L, Toxopeus HJ (1961) The effect of $R$-genes for hypersensitivity in potato-leaves on tuber resistance to Phytophthora infestans. Euphytica 10:35-42

Rouppe van der Voort J, van der Vossen E, Bakker E, Overmars $\mathrm{H}$, van Zandvoort P, Hutten R, Klein-Lankhorst R, Bakker J (2000) Two additive QTLs conferring broad-spectrum resistance in potato to Globodera pallida are localized on resistance gene clusters. Theor Appl Genet 101:1122-1130
Rudkiewicz F (1985) Zaraza ziemniaka (Phytophthora infestans (Mont) de Bary). In: Gabriel W (ed) Biologia ziemniaka Państwowe Wydawnictwa Naukowe. Warsaw, Poland, pp. 381398

Simko I, Constanzo S, Haynes KG, Christ BJ, Jones RW (2004) Linkage disequilibrium mapping of a Verticilium dahliae resistance quantitative trait locus in tetraploid potato (Solanum tuberosum) through a candidate gene approach. Theor Appl Genet 108:217-224

Slabaugh MB, Huestis GM, Leonard J, Holloway JL, Rosato C, Hongtrakul V, Martini N, Toepfer R, Voetz M, Schell J, Knapp SJ (1997) Sequence-based genetic markers for genes and gene families: single-strand conformational polymorphisms for the fatty acid synthesis genes of Cuphea. Theor Appl Genet 94:400-408

Smilde WD, Brigneti G, Jagger L, Perkins S, Jones JDG (2005) Solanum mochiquense chromosome IX carries a novel late blight resistance gene Rpi-moc1. Theor Appl Genet 110:252258

Song J, Bradeen JM, Naess SK, Raasch JA, Wielgus SM, Haberlach GT, Liu J, Kuang H, Austin-Philips S, Buell CR, Helgeson JP, Jiang J (2003) Gene $R B$ cloned from Solanum bulbocastanum confers road spectrum resistance to potato late blight. Proc Natl Acad Sci USA 100:9128-9133

Stewart HE, Bradshaw JE (2001) Assessment of the field resistance of potato genotypes with major gene resistance to late blight (Phytophthora infestans (Mont.) de Bary) using inoculum comprised of two complementary races of the fungus. Potato Res 44:41-51

Świeżyński KM (1990) Resistance to Phytophthora infestans in potato cultivars and its relation to maturity. Genetica Pol 31:99-106

Świeżyński KM, Zimnoch-Guzowska E (2001) Breeding potato cultivars with tubers resistant to Phytophthora infestans. Potato Res 44:97-117

Tanksley SD, Ganal MW, Prince JP, de Vincente MC, Bonierbale MW, Broun P, Fulton TM, Giovannoni JJ, Grandillo S, Martin GB, Messeguer R, Miller JC, Miller L, Paterson AH, Pineda O, Röder MS, Wing RA, Wu W, Young ND (1992) High density molecular linkage maps of the tomato and potato genomes. Genetics 132:1141-1160

Tommiska TJ, Hämäläinen JH, Watanabe KN, Valkonen JPT (1998) Mapping of the gene $N x_{p h u}$ that controls hypersensitive resistance to potato virus X in Solanum phureja IvP35. Theor Appl Genet 96:840-843

Toxopeus HJ (1958) Some notes of the relations between field resistance to Phytophthora infestans in leaves and tubers and ripening time in Solanum tuberosum subsp. tuberosum. Euphytica 7:123-130

Toxopeus HJ (1961) On the inheritance of tuber resistance of Solanum tuberosum to Phytophthora infestans in the field. Euphytica 10:307-314

Umaerus V, Umaerus M (1994) Inheritance of resistance to late blight. In: Bradshaw JE, Mackay GR (eds) Potato genetics. CAB International, Wallinford, pp. 319-337

Van der Vossen E, Sikkema A, te Lintel Hekkert B, Gros J, Stevens P, Muskens M, Wouters D, Pereira A, Stiekema W, Allefs $\mathrm{S}$ (2003) An ancient $R$ gene from the wild potato species Solanum bulbocastanum confers broad-spectrum resistance to Phytophthora infestans in cultivated potato and tomato. Plant J 36:867-882

Van der Vossen E, Gros JE, Sikkema A, Muskens M, Wouters D, Wolters P, Pereira A, Allefs S (2005) The Rpi-blb2 gene from Solanum bulbocastanum is an Mi-1 gene homolog conferring broad-spectrum late blight resistance in potato. Plant J 44:208-222 
Visker MHPW, Keizer LCP, van Eck HJ, Jacobsen E, Colon LT, Struik PC (2003) Can the QTL for late blight resistance on potato chromosome 5 be attributed to foliage maturity type? Theor Appl Genet 106:317-325

Visker MHPW, Heilersig HJB, Kodde LP, Van de Weg WE, Voorrips RE, Struik PC, Colon LT (2005) Genetic linkage of QTLs for late blight resistance and foliage maturity type in six related potato progenies. Euphytica 143:189-199

Wastie RL (1991) Breeding for resistance. Adv Plant Pathol 7:193-223

Zarzycka H (2001a) Evaluation of resistance to Phytophthora infestans in detached leaflet assay. Preparation of the inoculum. Plant Breeding and Acclimatization Institute, Radzików, Poland. IHAR Monografie i Rozprawy Naukowe 10a:75-77
Zarzycka H (2001b) Assessment of resistance to Phytophthora infestans in tuber slices and whole tubers. Plant Breeding and Acclimatization Institute, Radzików, Poland. IHAR Monografie i Rozprawy Naukowe 10a:78-80

Zhang LP, Lin GJ, Niňo-Liu D, Foolad MR (2003) Mapping QTLs conferring early blight (Alternaria solani) resistance in a Lycopersicon esculentum $\times$ L. hirsutum cross by selective genotyping. Mol Breed 12:3-19

Zimnoch-Guzowska E, Marczewski W, Lebecka R, Flis B, Schafer-Pregl R, Salamini F, Gebhardt C (2000) QTL analysis of new sources of resistance to Erwinia carotovora ssp. atroseptica in potato done by AFLP, RFLP, and resistance-gene-like markers. Crop Sci 40:1156-1167 